Olha Cherepekhina

ORCID iD 0000-0001-6970-1217

$\mathrm{PhD}$ (Psychology), Associate Professor, Associate Professor of the Department of Psychology and Pedagogy, Dnipropetrovsk State University of Internal Affairs, 26 Gagarina ave, 49005 Dnipro, Ukraine, olga.cherry.2013@gmail.com

\title{
THE CONCEPT RESEARCH OF DEVELOPMENT PEDAGOGICAL COMPETENCE OF A FUTURE TEACHER OF PSYCHOLOGY IN MAGISTRACY
}

The article is devoted to presentations the author's concept research of development pedagogical competence of a future teacher of psychology in a magistracy. Author build their own concept of further research based on such scientifictheoretical and methodological foundations such as: axiological; acmeological; activity; competence, professionography; system, personal and human-centered approaches. It is established that the phenomenon of pedagogical competence was studied by scientists from various conceptual approaches, which allowed the author to build his own concept of further research, based on scientific, theoretical and methodological principles.

Key words: acmeological approach; activity approach; axiological approach; competence approach; competence; concept research of development pedagogical competence of the teacher of psychology; master's training; pedagogical competence; pedagogical competence of the teacher of psychology; professionography approach; system approach.

https://doi.org/10.28925/1609-8595.2020.1.2

Introduction. Ukraine's higher education system has undergone significant changes for almost two decades, in particular, it has been challenged historically and culturally by the task of modernizing and improving education in all directions. There is a need to train specialists who are not only perfect at performing a given model of action, but also able to think critically and creatively, find new ways of solving educational and social problems, and be flexible to the new challenges of a rapidly changing reality. It is clear that training of specialists who will be able to educate such specialists in the future is an urgent need, and it is, first of all, about teachers of higher education institutions. This is especially true for the professional training of those specialists who will train other specialists in the future, completing the tasks of training in higher education institutions. Such educational goals are, in particular, fulfilled by teachers of psychology. In the modern conditions of modernization of training of specialists of pedagogical profile in higher education institutions the question of development of their competence as a teacher, teacher emerges. Here it is important to understand the content and structure of pedagogical competence, criteria and indicators of its formation, the conditions of its development in the process of study in the magistracy.

The purpose of the article is to develop the concept of research of development of pedagogical competence of the teacher of psychology in a magistracy.

Methodological foundations of concept development. Development of a methodology for researching the development of pedagogical competence of a future psychology teacher in terms of magistracy requires the development of an appropriate research concept. In describing the concept of the study, we adhere to the following sections (Yakovlev, Yakovleva, 2006, p. 171):

- terms;

- conceptual categorical apparatus;

- theoretical and methodological foundations;

- core;

- meaningful content;

- pedagogical conditions for the effective functioning and development of the phenomenon under study;

- verification.

So, let's start with the general terms. Our study refers to interdisciplinary research, as noted by S. Sysoieva (2011), these are studies that involve the interaction of different branches of scientific knowledge in the study of the same object of complex reality (p. 4). Our research integrates the knowledge of two related fields - pedagogy and psychology.

The logic of scientific search suggests that the phenomenon of pedagogical competence scientists have studied from a variety of conceptual approaches, which allow us to build our own concept of further research, based on the following scientific, theoretical and methodological bases:

- activity approach, representatives of which emphasize that the psychological study of professionalism is closely related to the problems of human development professional note the formative role of activity in the development of human psyche, from the standpoint of the activity approach in psychology and pedagogy 
professional development of the person is in the process of successful mastery of professional significant for her (V. Bodrov, A. Galaktion, E. Borisov, D. Zavalishin, E. Zeer, E. Klimov, T. Kudryavtsev, A. Markova, L. Mitina, K. Platonov, B. Ponomarev, G. Sukhodolskyi, V. Shadrykov, A. Fonareva etc.).

- professionography approach, according to which pedagogical competence is considered as the readiness of the specialist to perform various functions of pedagogical activity on the basis of deep learning of pedagogical knowledge, skills as well as through the pedagogisation of his higher psychic functions (V. Slastionin, V. Khmelyun, O. Khmelian etc., 2002);

- acmeological approach in which the pedagogical competence is considered as the basic qualitative characteristic connected with the achievement of the specialist of higher levels of pedagogical skill and professionalism on the basis of motivation for continuous professional self-perfection and creativity as the organizer, the main participant and the manager of training (N. Kuzmina, A. Markova, etc., 1996);

- axiological approach, within which pedagogical competence is represented as the main educational value, since it involves the immersion of personality in the cultural world of values - pedagogical culture, which determines its formation as a teacher-educator and teacher (M. Vasilyeva, G. Virna, I. Isaev, L. Kondrashova, 2003, 2011);

- competence approach, whose supporters determine the pedagogical competence of socially and personally meaningful end result of the corresponding vocational training, which will ensure the mobility and competitiveness of the specialist in the field of personto-person professions due to the ability to use effective ways of solving educational and educational orientation, positive attitudes and motivations (A. Verbitsky, O. Ovcharuk, L. Paraschenko, O. Pometun, O. Savchenko, L. Khoruzha etc., 2004, 2017);

- system approach to understanding the pedagogical competence of the teacher of psychology makes it possible to investigate the development of pedagogical competence in future teachers of psychology from the standpoint of the integrity and interdependence of its structural components, and allows you to consider pedagogical competence as an open socio-pedagogical system, separate components and structures them (B. Ananiev, G. Kostyuk, K. Platonov, B. Lomov etc., 1994, 2016);

- personal and human-centered approaches to the necessary component in the study of pedagogical competence of a teacher of psychology indicate the need to develop and use a personally-oriented set of methods of training, stimulation, development and realization of the creative potential of a person as a whole personality (K. Abulkhanova-Slavska, B. Ananyev, G. Ball, I. Beh, O.Bodalev, L. Bozovich, N. Boryshevsky, L. Vygotsky, M. Gulin, I. Zyazun, G. Kostyuk, O. Kirichuk, S. Maksimenko, V. Molyako, I. Manokha, V. Rybalka and others).

The above scientific approaches to understanding pedagogical competence lead to the choice of the subsequent logic of the research search. In the current methodology, there are several basic approaches that we will rely on in our research.

Systematic approach. The fundamental level of general scientific methodology is represented by a systematic approach, the emergence of which in philosophy, cybernetics, sociology, semantics in the 1960s stimulated a qualitatively new stage in the development of the methodology of scientific knowledge, although the traditions of systemic worldview, holistic awareness of L. Vygotsky, P. Florensky. The so-called «system movement», «system boom» in science ended with the design of an independent branch of knowledge - systemology, or the general theory of systems, which made a significant contribution to the development of B. Ananiev, V. Afanasyev, I. Blauberg, R. Gurova, I. Kon, A. Derkach, V. Myasishchev, V. Sadovsky, G. Shchedrovitsky, E. Yudin, A. Kharchev. The scientific value of a systematic approach is generally determined by its value as a single principle that reflects the worldview level of the research; as a universal method of knowledge; as a technology of research that opposes the spontaneity and subjectivism, creates the conditions for the consistency and stability of scientific research (Guziy, 2015).

In the process of researching theoretical and methodological foundations of the development of pedagogical competence of the teacher of psychology, the essence and mechanisms of its appearance in the structure of his personality, we relied on the principle of systematic and in general on system methodology (V. Afanasiev, V. Kuzmin, N. Sadovsky, K. AbulkhanovaSlavskaya, A. Bodalev, D. Bruner, L. Vigotsky, B. Lomov, N. Kuzmina, K. Platonov, A. Sitnikov etc.).

Without justifying the structure of the studied phenomenon and understanding it as a system of subordinate elements, as well as understanding it as an element of a complex broader system of personality of a professional, it is impossible to start scientific research. The systematic approach is considered as a direction of methodology of special scientific knowledge and sociopedagogical practice, which is based on the principle of systematic nature. It is based on the study of objects as systems; its application guides the researcher to discover the integrity of the object, to identify the various types of communication within its boundaries and to bring them into a single theoretical picture (Y. Popkova, V. Sadovsky, V. Tishchenko, 2012, p. 20-21).

Taking into account the ideas of the systemic approach emphasizes the need to develop integrated educational systems that include many interconnected components and links between them. The system-functional approach considers the interaction of components, which ensures the new quality of a holistic system. Systematic approach affirms the causal nature of processes and phenomena, hierarchy in the construction and design of pedagogical systems.

The study of pedagogical competence from the standpoint of a systematic approach implies that «a 
system object is not given to the researcher directly, directly as a system, but acts as a result of comparing the complex, contradictory and yet interdependent properties and characteristics of the object, the explicit expression of the systematic and how a prerequisite is the transition from phenomenal fixation of object properties to special theoretical construction of models that most adequately reveal the system structure and essence of the object» (Kazmirenko, 1993, p. 166). The direction of such research requires a description of the mechanisms for the holistic functioning of such an object.

Understanding the pedagogical competence of a future psychology teacher as a system allows, given the systemic linkages between elements of the system (components of pedagogical competence), to take into account the interplay of one element to another, to optimize this influence and to avoid unwanted effects. According to N. Sidorchuk, O. Dubaseniuk the standpoint of a systematic approach, the study of professional and pedagogical training of university students involves the uncovering of the dynamic nature of the diversity of structural manifestations of interconnections (external and internal) and the interdependencies of all its elements and subsystems in a single construction of the whole. An important aspect of scientific research here is the search for those characteristics and properties that provide stability, preservation of this phenomenon and determine the type and direction of its changes (Sidorchuk, 2017, p. 84).

We agree with V. Oleksiyenko's position, who claims that the implementation of a systematic approach to the study of objects involves the following sequential procedures: fixation of some set of elements, separated from others; defining and classifying the internal links of this set, that is, the links between elements and subsystems of sets; determining, based on an analysis of the set of external relationships, the principles of system interaction with the environment Selection of a set of internal links of a special type of connection - systemforming, which ensure the ordering of the system; detection in the process of analyzing the ordering of elements in the system; analysis of the basic principles of behavior of the system as a whole set; study of management processes that ensure the stability of the system and achieve the planned results (Oleksiyenko, 2007, p. 79).

That is why we have identified in the professional training of future teachers of psychology some set of qualities and competences that are important to form during professional training, identified pedagogical competence from other competencies, identified among its elements key competences, presented them as systemforming in pedagogical structure of pedagogical marking them as ensuring the ordering of pedagogical competence as a system, we study the processes and pedagogical conditions that have holders, system stability and achieve the intended result - highly professionally competent specialists in their field: psychology teacher in higher education.

From the standpoint of the systematic approach, in our study of the development of pedagogical competence of the teacher of higher education as a process, it is important to reveal the dynamic nature of the diversity of structural manifestations of interconnections (external and internal) and interdependencies of all its elements and subsystems in a single construction of the whole. An important aspect of the work here is the search for those characteristics and properties that provide stability, preservation of this phenomenon and determine the type and direction of its changes.

Pedagogical competence is considered by us as a component (subsystem) of a larger in relation to it in this case system called «professionalism of the teacher of psychology of high school». Professionalism, viewed from the standpoint of a systematic approach, is not a static (once given, unchanged) but a dynamic formation that is constantly changing. In the process of mastering the professional role of the professionally important qualities of the future teacher of psychology as a potential specialist, the techniques of their orderliness and compensation are developed, the activity acquires qualitatively new characteristics (A. Markova). The «specific gravity» of individual PSFs changes as they move from the lower level of professional success to the higher (M. Dmitriev, S. Druzhilov).

The systemic nature of pedagogical competence determines the expediency of its development through the development of its structural components, competences. The need for a systematic approach to the study of professional development Teacher of psychology at the stage of master's training is explained by the provision of B. Lomov said that the mental properties of the individual can not be revealed neither as functional nor, moreover, as material and structural. They belong to the category of properties that are defined as systemic. This approach involves considering an individual possessing personal qualities as an element of some developing system.

System methodology allows us to explore the future psychology teacher as an open self-regulating system, the functioning of which is possible in the presence of feedback between the system and the environment. This means that a sufficiently complete study of the personal and professional development of a future psychology teacher is supersystematic in relation to the development of pedagogical competence and requires the study of the multidimensional relationship of this subsystem, part of which is a person, with the subsystem of the educational process in universities, subsystems of interpersonal relationships schools, families), the subsystem of relations of society in general, and others. This system is deployed through educational and cognitive and professional activities, such as interaction with a student, a teacher, a training group. Apparently oriented interaction (with the teacher, with classmates, etc.) forms the necessary side of his professional activity, and professional knowledge and skills are an important and necessary component of his skill.

Therefore, pedagogical competence should be considered not as a simple set of signs (symptoms), 
but as a more complex subsystem of the system of professionalism of the teacher of psychology in institutions of higher education. Therefore, in the general context, in our study, the systematic approach refers to the methodological direction that develops the means of knowing and developing complexly organized objects. If we draw historical analogies, then this approach has replaced the mechanistic methodology, focused on the study of individual, as a rule, immutable elements of reality, the movement of which is subject to the laws of classical mechanics. Unlike the mechanism (machine), that is, the outer coupling of parts, the system is a qualitative unity or set that has integral properties. This understanding gives us the opportunity to explain the movement of higher education pedagogy from the mechanistic reproduction of a specialist «psychology teacher» according to his profession and state standards towards the development of a pedagogically competent specialist, whose professional competence forms a qualitative structure characterized by integral features.

In contrast to the traditional organization of the system of teaching in the higher school of future teachers of psychology, we want to emphasize the specificity and variety of holistic manifestations of the teacher's professional competence, their dependence on the sphere of being, the level of their own organization and development. Based on the ideas of B. Lomov, we consider it necessary to formulate the position that the future teacher of psychology, it is primarily a person (her psyche, needs, behavior, interests), including in different systems of relationships, unfolds in different plans and reveals qualities that are not available in other systems. As there are several such systems, pedagogical competence acts as a kind of «qualitative knot» in the system of relations and being a personality of the future teacher of psychology.

As a system, based on the provisions of B. Lomov, we consider not only the investigated pedagogical competence, but also ways of its development and manifestation. Therefore, a systematic approach involves a variety of sources and drivers of the professional and mental development of the person, which is always connected with the system of contradictions and provides different ways of solving them. Any developmental outcome (professional, social, cognitive, personal, operational) achieved at one stage or another is included in the aggregate determination of personality, acting as internal factors, prerequisites, or mediating links in relation to the result of the next stage.

Studying the development of the pedagogical competence of a future teacher from the standpoint of a systematic approach generally requires him to be considered simultaneously in several plans. The first plan represents the personal level. The second plan presents the whole set of activities as a relatively independent entity. As components they need to be differentiated, which we have taken into account when developing the structure of pedagogical competence.

Thus, from the standpoint of a systematic approach, the pedagogical competence of the future psychology teacher in higher education institutions is defined by us as the systematic formation and subsystem of personality professionalism in the structure as the subject of the educational process of the subsystem of interpersonal relations in the institutions of higher education in the subsystems of our society.

Conclusions. Thus the methodological bases of the concept of development of pedagogical competence of future teachers of psychology in the conditions of the master's preparation claim the scientific status of a complex approach - a scientific approach to the knowledge of such complex phenomenon, which is a pedagogical competence, which works as a general requirement, as a law. When considering a complex approach, it acquires the rank of a fundamental principle that reflects the main, essential aspects of pedagogical competence of future teachers of psychology, determines the end result - a highly professional teacher of psychology in institutions of higher education.

In order to determine the pedagogical competence of a future psychology teacher, it is necessary to check its compliance with the selected structure and criteria of pedagogical competence, so we proceed to the description of the ascertainment experiment.

Prospects for further research in order to develop the technology of psychological and pedagogical support for the development of pedagogical competence in future teachers of psychology in the context of digitalization.

\section{References}

Adolf, V. A. (1998). Formirovanie professionalnoj kompetentnosti budushogo uchitelya [Formation of professional competence of the future teacher]. Pedagogika, 1, 72-75.

Alekseenko, V. A. (2007). Sistemnyj podhod k upravleniyu kachestvom obrazovatelnoj deyatelnosti vuzov Rossii [A systematic approach to quality management of educational activity of Russian universities]. Izdatelstvo Nacionalnogo instituta biznesa.

Bibik, N. M., Vashenko, L. S., Lokshina, O. I., Ovcharuk, O. V., Parashenko, L. I. (2004). Kompetentnsnij pidhid u suchasnij osviti: soitovij dosvid ta ukrayinski perspektivi: monografiya [Competent Approach in Contemporary Education: World Experience and Ukrainian Perspectives: A Monograph]. K.I.S.

Vasilyeva, M. P. (2011). Aktualni problemi pidgotovki majbutnogo socialnogo pedagoga dlya osvitnoyi galuzi v suchasnih umovah [Actual problems of preparation of the future social pedagogue for the educational field in modern conditions]. Pedagogika ta psihologiya, 40 (1), 110-116.

Verbitsky, A. A. (2004). Kompetentnostnyj podhod i teoriy a kontekstnogo obucheniya [Competence approach and theory of context learning]. Issledovatelskij centr problem kachestva podgotovki specialistov. 
Virna, Zh. P. (2003). Motivacijno-smislova regulyacya u profesionalizaciyi psihologa [Motivational and semantic regulation in the professional psychologist]. Vezha.

Isaev, I. F. (1986). Teoriya i praktika formirovaniya professionalno-pedagogicheskoj kultury prepodavatelya vysshej shkoly [Theory and practice of forming the professional and pedagogical culture of a teacher of higher education]. MGPU.

Kazmirenko, V. P. (1993). Socialnaya psihologiya organizacij: monografiya [Social psychology of organizations: monograph]. KiMZUUP.

Kondrashova, L. V. (1990). Metodika podgotovki budushego uchitelya $k$ pedagogicheskomu vzaimodejstviyu $s$ uchashimisya [Methods of preparing a future teacher for pedagogical interaction with students]. Prometheus.

Kuzmina, N. V., Rean, A. A. (1993). Professionalizm pedagogicheskoj deyatelnosti [Professionalism of pedagogical activity]. SPbGu.

Livshic, V. N., Livshic, S. V., Tishenko, T. I., Frolova, M. P. (2011-2012). Osnovy sistemnogo myshleniya i sistemnogo analiza [Fundamentals of system thinking and system analysis]. Metodologicheskie problemy. Sistemnye issledovaniya, 36, 5-51.

Markova, A. K. (1996). Psihologiya professionalizma [Psychology of professionalism]. Mezhdunarodnyj gumanitarnyj fond Znanie.

Guziy, N. V. (Ed.) (2015). Pedagogichna tvorchist, majsternist, profesionalizm u sistemi pidgotovki osvityanskih kadriv: zdobutki, poshuki, perspektivi: monografiya [Pedagogical creativity, skill, professionalism in the system of training of educational personnel: achievements, searches, perspectives: monograph]. NPU imeni M. P. Dragomanova.

Sidorchuk, N. G. (2017). Problema profesijno-pedagogichnoyi osviti: teoretikometodologichni zasadi doslidzhennya [The Problem of Vocational Education: Theoretical and Methodological Foundations of the Study]. In Profesijna pidgotovka fahivciv: kreativnij pidhid / Sidorchuk N. G., Dubasenyuk O. A., Antonova O. Ye. (pp. 82-120). Vidavnictvo Yevenok O. O.

Sysoieva, S. O. (2011). Pedahohichna kompetentnist' vykladacha vyschoho navchal'noho zakladu nepedahohichnoho profiliu [Pedagogical competence and the responsibility for a higher primary mortgage of a non-pedagogical profile]. In Kompetentnisnij pidhid u suchasnij universitetskij osviti: zbirnik naukovih prac (pp. 3-11). NUVGP.

Slastenin ,V. A., Isaev, I. F., Shiyanov, E. N. Pedagogika [Pedagogy]. Akademiya.

Khoruzha, L., Bratco, M. (2017). Pedagogika vishoyi shkoli: suchasni didaktichni strategiyi [Pedagogy of the Higher School: Modern Didactic Strategies]. Nepererona profesijna osvita: teoriya i praktika, 1-2, 7-13. https://doi. org/10.28925/1609-8595.2017(1-2)713.

Yakovlev, E. V., Yakovleva, N. O. (2006). Pedagogicheskaya koncepciya: metodologicheskie aspekty postroeniya [Pedagogical concept: methodological aspects of construction]. VLADOS.

\section{Література}

Адольф В. А. Формирование профессиональной компетентности будущого учителя. Педагогика. 1998. № 1. C. $72-75$.

Алексеенко В. А. Системный подход к управлению качеством образовательной деятельности вузов России. Москва: Издательство Национального института бизнеса, 2007. 223 с.

Бібік Н. М., Ващенко Л. С., Локшина О. І., Овчарук О. В., Паращенко Л. І. Компетентнсний підхід у сучасній освіті: світовий досвід та українські перспективи: монографія. Київ: К.І.С., 2004. 112 с.

Васильєва М. П. Актуальні проблеми підготовки майбутнього соціального педагога для освітньої галузі в сучасних умовах. Педагогіка та психологія. 2011. Вип. 40 (1). С. 110-116.

Вербицкий А. А. Компетентностный подход и теория контекстного обучения. Москва: Исследовательский центр проблем качества подготовки специалистов, 2004. 84 с.

Вірна Ж. П. Мотиваційно-смислова регуляція у професіоналізації психолога. Луцьк: Вежа, 2003. 320 с.

Исаев И. Ф. Теория и практика формирования профессионально-педагогической культуры преподавателя высшей школы. Москва: МГПУ, 1993. 219 с.

Казмиренко В. П. Социальная психология организаций: монография. КиМЗУУП, 1993. 384 с.

Кондрашова Л. В. Методика подготовки будущего учителя к педагогическому взаимодействию с учащимися. Москва: Прометей, 1998. 160 с.

Кузьмина Н. В., Реан А. А. Профессионализм педагогической деятельности. Санкт-Петербург: СПбГУ, 1993. $63 \mathrm{c}$.

Лившиц В. Н., Лившиц С. В., Тищенко Т. И., Фролова М. П. Основы системного мышления и системного анализа. Методологические проблемы. Системные исследования. Ежегодник 2011-2012. Вып. 36. С. 5-51.

Маркова А. К. Психология профессионализма. Москва: Международный гуманитарный фонд Знание, 1996. $312 \mathrm{c}$.

Педагогічна творчість, майстерність, професіоналізм у системі підготовки освітянських кадрів: здобутки, пошуки, перспективи: монографія / керівник авторського колективу Н. В. Гузій. Київ: НПУ імені М. П. Драгоманова, 2015. 432 с. 
Сидорчук Н. Г. Проблема професійно-педагогічної освіти: теоретико-методологічні засади дослідження. Професійна підготовка фахівців: креативний підхід / Сидорчук Н. Г., Дубасенюк О. А., Антонова О. Є. та ін. Житомир: Видавництво Євенок О. О., 2017. С. 82-120.

Сисоєва С. О. Педагогічна компетентність викладача вищого навчального закладу непедагогічного профілю. Компетентнісний підхід у сучасній університетській освіті: збірник наукових праць. Рівне: НУВГП, 2011. C. 3-11.

Сластенин В. А., Исаев И. Ф., Шиянов Е. Н. Педагогика. Москва: Академия, 2013. 576 с.

Хоружа Л., Братко М. Педагогіка вищої школи: сучасні дидактичні стратегії. Неперервна професійна освіта: теорія і практика. 2017. № 1-2. C. 7-13. DOI: https://doi.org/10.28925/1609-8595.2017(1-2)713.

Яковлев Е. В., Яковлева Н. О. Педагогическая концепция: методологические аспекты построения. Москва: ВЛАДОС, 2006. 239 с.

\title{
КОНЦЕПЦІЯ ДОСЛІДЖЕННЯ РОЗВИТКУ ПЕДАГОГІЧНОЇ КОМПЕТЕНТНОСТІ МАЙБУТНЬОГО ВИКЛАДАЧА ПСИХОЛОГІЇ В УМОВАХ МАГІСТРАТУРИ
}

\author{
Черепєхіна Ольга, кандидат психологічних наук, доцент, доцент кафедри психології та педагогіки, \\ Дніпропетровський державний університет внутрішніх справ, \\ просп. Гагаріна, 25, 49005 Дніпро, Україна, olga.cherry.2013@gmail.com
}

Стаття присвячена обгрунтуванню авторськоїконцепціїдослідження розвитку педагогічноїкомпетентності майбутнього викладача психологї в умовах магістратури. Автор будує власну концепцію дослідження на основі таких науково-теоретичних і методологічних основ, як аксіологічний; акмеологічний; компетентнісний, діяльнісний, професіографічний; системний, особистісний-орієнтований підходи. проаналізовані названі підходи. Встановлено, що представники діяльнісного підходу відзначають формуючу роль діяльності в розвитку психіки людини; згідно з положеннями професіографічного підходу педагогічна компетентність розглядається як готовність фахівия виконувати різноманітні функцї педагогічної діяльності; акмеологічний підхід розглядає педагогічну компетентність як базову якісну характеристику, пов'язану 3 досягненням фахівцем вищих рівнів педагогічної майстерності та професіоналізму; у межах аксіологічного підходу педагогічна компетентність представляється як найголовніша освітня цінність; прибічники компетентнісного підходу визначають педагогічну компетентність соціально і особистісно значущим кінцевим результатом відповідної - професійно-педагогічної підготовки; системний підхід досліджує розвиток педагогічної компетентності у майбутніх викладачів психологї із позицій цілісності та взаємозумовленості ї̈ структурних складових; відповідно до особистісного підходу, необхідною складовою у дослідженні педагогічної компетентності викладача психологї зазначається необхідність розробки та використання особистісно орієнтованого комплексу методів навчання, стимуляції, розвитку та реалізацї творчого потенціалу людини як иілісної особистості. У статті представлена авторська конщепція дослідження розвитку педагогічної компетентності майбутнього викладача психологї, що грунтується на науково-теоретичних та методологічних засадах.

Ключові слова: аксіологічний підхід; акмеологічний підхід; діяльнісний підхід; компетентнісний підхід; компетентність; розвиток педагогічної компетентності викладача психологї; магістерська підготовка; педагогічна компетентність; педагогічна компетентність викладача психологї; професіографічний підхід; системний підхід.

\section{КОНЦЕПЦИЯ ИССЛЕДОВАНИЯ РАЗВИТИЯ ПЕДАГОГИЧЕСКОЙ КОМПЕТЕНТНОСТИ БУДУЩЕГО ПРЕПОДАВАТЕЛЯ ПСИХОЛОГИИ В УСЛОВИЯХ МАГИСТРАТУРЫ}

\footnotetext{
Черепехина Ольга, кандидат психологических наук, доцент, доцент кафедры психологии и педагогики, Днепропетровский государственный университет внутренних дел, просп. Гагарина, д. 26, 49005 Днепр, Украина, olga.cherry.2013@gmail.com
}

Статьяпосвященапрезентацииавторскойконцепщииисследованияразвитияпедагогическойкомпетентности будущего преподавателя психологии в магистратуре. Автор строит собственную концепцию исследования на основе таких научно-теоретических и методологических основ, как аксиологический; акмеологический; компетентностный, деятельностный, профессиографический; системный, личностный-ориентированный подходы. Установлено, что феноменпедагогическойкомпетентностиученые изучалисразличныхконцептуальных подходов, которые позволили автору построить собственную концепцию дальнейшего исследования, основанный на научно-теоретических и методологических принципах.

Ключевые слова: аксиологчческий подход; акмеологический подход; деятельностный подход; компетентностный подход; компетентность; конщептуальное исследование развития педагогической компетентности преподавателя психологии; магистерская подготовка; педагогическая компетентность; педагогическая компетентность преподавателя психологии; профессиографический подход; системный подход. 